\title{
Kulturális kölcsönhatások nyomai a beregszászi református temetőben
}

Kárpátalja több évszázados fejlődése során többnemzetiségű, kulturálisan vegyesnek mondható lakosságra tett szert a történelmi sorsfordulók következtében. Ennek értelmében elkerülhetetlennek tekinthetjük a kulturális kölcsönhatásokat a lakosság nyelvhasználatában és népi hagyományaiban, szokásaiban. Nem volt ez másképp a megye legnagyobb számú élő magyar ajkú lakosságával rendelkező városában, Beregszászban sem. A legutóbbi, 2001-es népszámlálás eredményei alapján a 26554 föt számláló település ukrán, magyar, román, orosz, cigány, szlovák, német és belorusz nemzetiségü lakossággal rendelkezett. Ezáltal nemcsak a nyelvi sokszínűség jellemző a városban, hanem vallási megosztottság is. Beregszász 3 temetővel rendelkezik: zsidó, római katolikus és református, amelyek közül utóbbi a legnagyobb kiterjedésü. Hipotéziseimben a fent említett kulturális kölcsönhatások jelen vannak a beregszászi református temetőben, melynek elnevezése mára már szimbolikus. A sírkert tartalmának nemzetiségi összetétele, a sírfeliratok nyelvezete és sajátos szimbólumvilága hüen tükrözi a településen zajló demográfiai és politikai változásokat, amelyek nagy hatással voltak a lakosság mindennapi életére, gondolkodására.

A temető szoros kapcsolatban van a településsel, amelyhez tartozik, múltjának része, s e múlt megismerésének egyik forrása.

A temető - a halott falu - az élő falu társadalmi képét tükrözi. Középkori hagyomány nyomán a legtöbb temető a templom körül helyezkedett el és a bokros temetkezés jellemezte. A 18. század óta a sírokat nem rendezték égtájak felé, hanem soros temetkezés alakult ki, a halottakat halálozási sorrendjükben temették, nem családi, rokoni kapcsolat szerint. ${ }^{1}$

Mivel az első világháborút lezáró békeszerződések aláírásáig a mai Kárpátalja területe a Magyar Királyság Ung, Bereg, Ugocsa és részben Máramaros megyéjét alkotta, a temetők kialakulása ezen a területen is hasonló fejlődési utat járt be, mint az ország többi részében, így a fent leírt jellemzők a kárpátaljai több évszázados múlttal rendelkező települések temetőire is érvényesek. Eltérés csak a 20. századi temetőfejlődésben mutatkozik, mivel a több hatalomváltást megélt Kárpátalja magyar települései és egyben temetői is átalakultak: nemzetiségi és vallási téren egyaránt vegyesek, színesek lettek. Sok helyen megmaradt a temetők felekezeti jellege és a temetők leképezik a falu nemzetiségi viszonyait.

${ }^{1}$ KUNT ERNŐ: Temetők népmüvészete. Bp., 1983. 32. 
A temetők megnevezései arra utalnak, hogy a kialakulásuknál döntő szempont volt a vallási hovatartozás. Ez a kizárólagosság ma már csak a zsidó temetőkre vonatkozik, amelyek vallási hovatartozás szempontjából a mai napig homogének. A beregszászi református temetőbe a katolikusok a 20. század második felétől kezdtek el temetkezni. Ennek okát talán - ugyanúgy mint a Felvidéken - abban is lehet keresni, hogy akkorra szinte teljesen megszüntek azok a ,hagyományos kötöttségek", amelyek korlátozták a vallásilag vegyes házasságokat. ${ }^{2}$

\section{A beregszászi református temető általános jellemzése}

A beregszászi református temető páratlan történelmi emlék, amely sokat segíthet Beregszász történelmének és fejlődésének, polgárai életének tanulmányozásában, megismerésében.

A városban három: az ún. református (mely csak részben az), a katolikus és a zsidó temető található. Ezek közül a legnagyobb területtel a református rendelkezik. Mint már korábban jeleztem, a beregszászi református temető mára már tartalmilag vallási tekintetben felhígult, így nem csak protestáns jelképeket, hanem római katolikus, görög katolikus és pravoszláv keresztekkel is találkozunk területén.
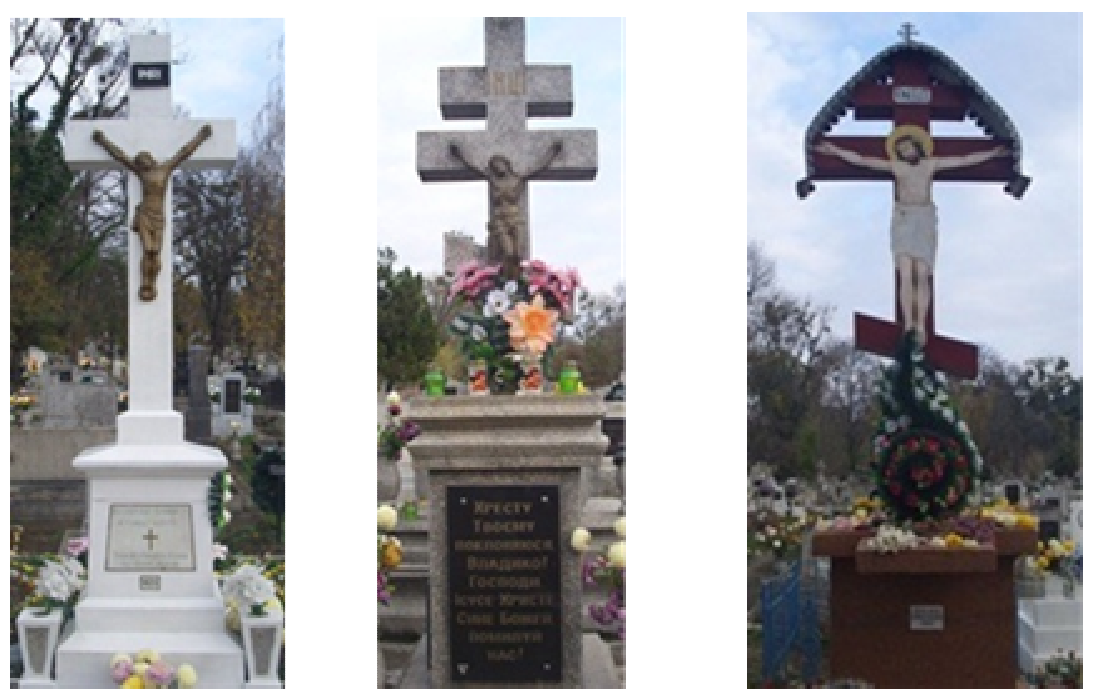

A temető egykori arculata, szerkezete napjainkra teljesen megváltozott. A régi temető, vagyis a régebbi rész jóval keletebbre helyezkedett el, mint a jelenlegi. Valószínü, hogy a régebbi sírok a jelenleg müködő Mustang sportcentrum, valamint a temető közvetlen szomszédságában lévő tüdőgondozó kórház területén lehettek. ${ }^{3}$

\footnotetext{
${ }^{2}$ PUNTIGÁN JózSEF-PUNTIGÁn TÜNDE: A losonci református temető. Komárom-Dunaszerdahely, 2003. 24.

${ }^{3}$ MAHURSZKI ANETT: Adalékok a beregszászi református temetö történetéhez és jellemzéséhez. Acta Beregsasiensis. A II. Rákóczi Ferenc Kárpátaljai Magyar Főiskola tudományos évkönyve X, 2011. 1. k. 146.
} 
A legkorábbi - az 1840-1860-as években állított - sírok többsége nagyon rossz állapotban van. Ennek oka a homokos talaj, ami miatt lecsúszott a föld a hegyröl, és betemette a sírköveket. Szintén kevés síremlék maradt épségben 20. századunk 10'40'-es éveiből, ám itt nagy szerepet játszott elhanyagolt állapotuk is. ${ }^{4}$

A 19. századtól a 20. század 40-es évekig terjedő időszaka sírjainak megtalálását nehezítette a pontos temetkezési rendszer hiánya ezen időszakban, a sírok és a temető bővülése koncentrikusan, mindig a szélek felől zajlott. Egyes sírokból alig maradt fenn valami, sok esetben hiányzik a hagyományos kelet-nyugati irányú testhelyzet.

\section{A beregszászi református temető tartalmának nemzetiségi összetétele névanyagának vizsgálata alapján}

Kárpátalján a történelmi sorsfordulók következtében rendkívül gyakran történtek demográfiai változások. Az adatokat rögzítő táblázatokból jellemző képet nyerhetünk többek között a népszaporodásról, a migrációról, az elhalálozásokról, a születésekröl, stb. Különös, hogy nem arányos a járások lakosságának szám szerinti megoszlása. A járások lakosságszámához viszonyítva a városok népessége jelentősen elmaradt. A legtöbb város népessége a 10000 föt sem érte el, kiemelkedő ebben a tekintetben Beregszász, amely 1910-ben 12900 lakossal büszkélkedhetett. Ám a beregszászi járás lakossága (ahol a legtöbb magyar él a mai napig) 1944-től 1991-ig 56300-ról 85500-ra gyarapodott. Dr. Árpa István szerint „minden nagy történelmi és politikai esemény: korszakváltás, egyben kultúraváltás. A demográfiai adatok arra is rámutatnak, hogy a városok lakosságának összetétele nagyon sokrétü. (Talán valamivel kevésbé jellemző ez a falvakon). A városok (hivatalok, minisztériumok, közigazgatási szervek) által irányított közmüvelödés kihatott a járásokra, a vidékre. Volt tehát mindig egy közigazgatási nyelvhasználat (legtöbbször az ún. „államnyelv”), népnyelv és a nemzetiségek anyanyelve.",

Hasonló korszakváltások figyelhetőek meg a beregszászi református temetőben, mely korábban szinte csak magyar sírfeliratokat tartalmazott, a 20. század '20-as éveitől mára találhatunk benne a magyar mellett orosz, ukrán és cseh sírfeliratokat is.

A beregszászi református temető hozzávetőlegesen 7006 db sírt tartalmaz, melynek síremlékein olvasható feliratok több mint a fele magyar nyelvezetü.

A kutatás kezdetekor legelöször a temetö körbejárására, majd annak térképének megrajzolására került sor. A sírkert területét 20 parcellára osztottuk, amelyeket az ábécé betüivel különböztettünk meg. Az alábbi térkép a temető elhelyezkedését és felosztását mutatja be:

\footnotetext{
${ }^{4}$ RAZGULOV, VALERIJ: A beregszászi református temető történetéről. Beregszász hetilap, 2000. június 22.

5ÁRPA IsTVÁN: A tiszaháti nemzetiségek életéből. Pillanatképek múltunkbó). Ungvár-Bp., 1993. 23-26.
} 


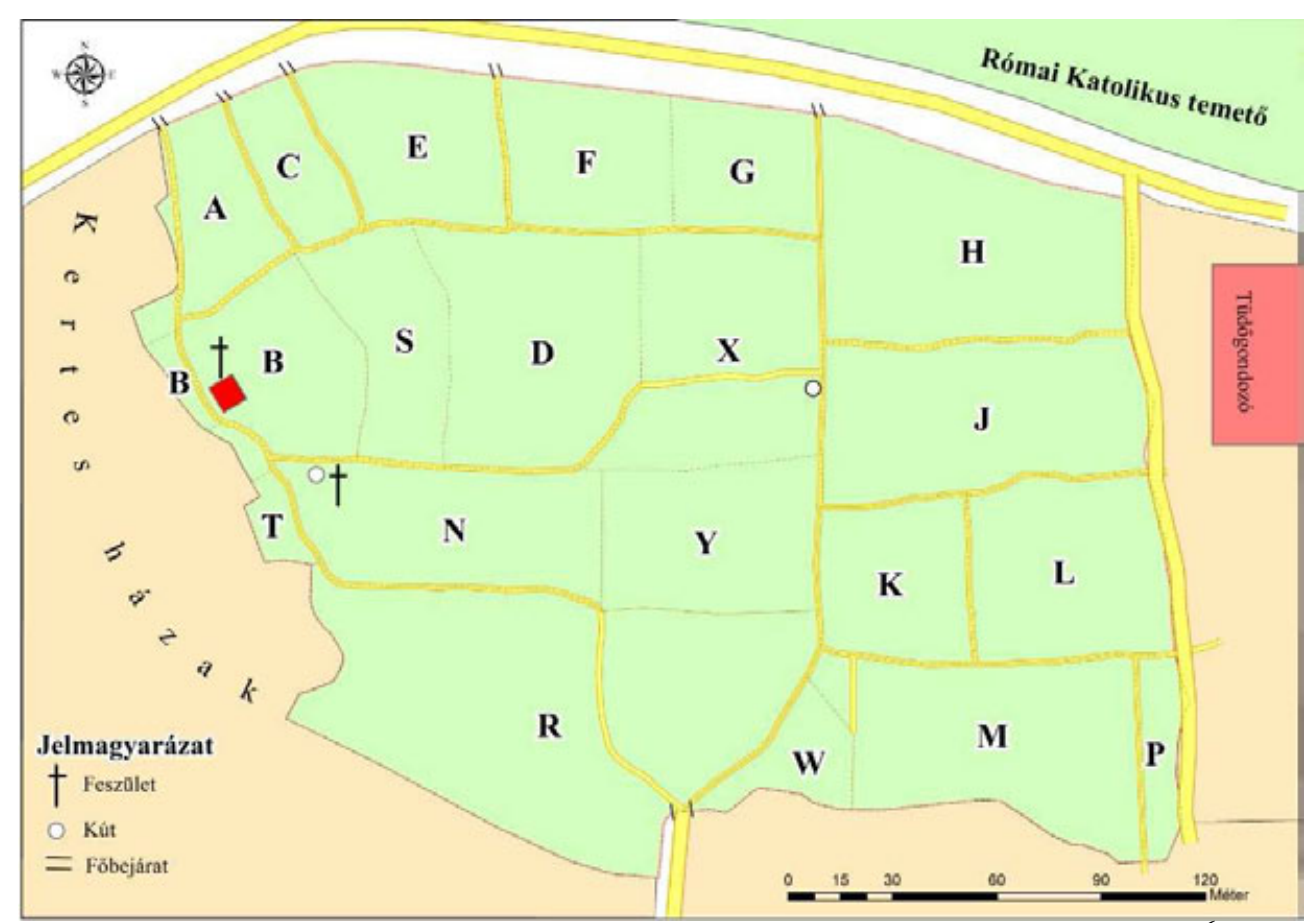

1. térkép: A beregszászi református temető parcellákra felosztott térképvázlata. ${ }^{6}$

Ezután megszámolásra kerültek külön-külön parcellánként a sorok, valamint azokon belül a magyar és egyéb nyelvezetủ sírok. Ezáltal egy teljes kép kapható arról, hogy a temető már sem nemzetiségileg, sem vallásilag nem „tiszta”, hanem az idők során nemcsak görög és római katolikusok, hanem pravoszláv vallásúak is temetkeztek oda.

A parcellákban számolt magyar és más nyelvű sírok fekvése utal arra, hogy hol lehettek a legkorábbi magyar sírok és hová temetkeznek az 1944-es szovjet-ukrán hatalomváltás óta a szláv nemzetiségüek. A parcellák nem egyenlően vannak elosztva, leginkább a sétaösvények szolgáltak elválasztó vonalként. A következő diagram a sírok számát mutatja be egy-egy parcellán belül:

${ }^{6}$ Saját szerkesztés. 


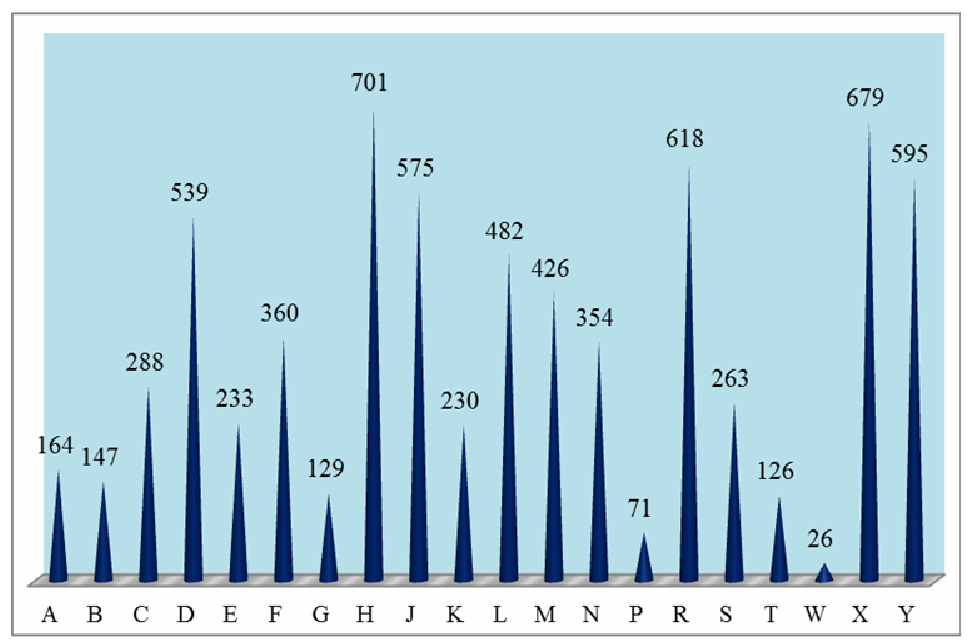

\section{1. diagram: A beregszászi református temető parcelláiban található sírok száma. ${ }^{7}$}

Az ezután következő diagram ugyan ezen adatoknak a százalékos kimutatását jelöli:

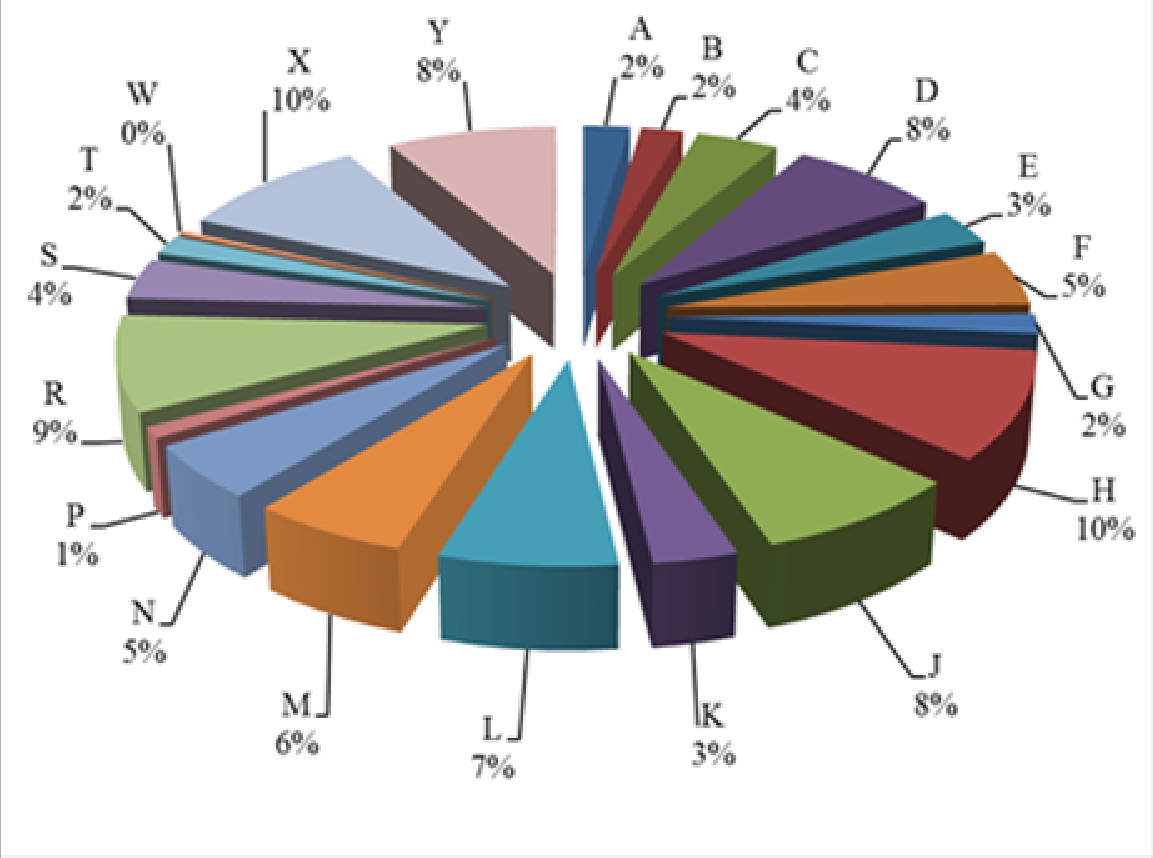

2. diagram: A beregszászi református temetö sírjainak parcellákra való százalékos eloszlása. ${ }^{8}$

A temető legrégebbi sírjai többségben az északi, északkeleti, valamint a keleti részen találhatók, többnyire honvédek nyughelyei és az 1840-es évekből maradtak

${ }^{7}$ Saját szerkesztés.

${ }^{8}$ Saját szerkesztés. 
ránk, a sírfelirataik rossz állapota miatt a pontos adatok jórészt olvashatatlanok. A legújabbak értelemszerúen a déli és a déli és délnyugati részen vannak, mivel itt bővítették utoljára a temetőt.

Elmondhatjuk, hogy a legtöbb magyar sír a C, D, X, F, G, H, K, L, parcellákban van, ez azt is magyarázza, hogy a legfrissebben odatemetkezetteket az A, T, N, S, P jelü osztásokban vannak, vagyis a temető a peremén. Míg a D, E, F, G, H parcellák, amelyek a sírkert közepén és az út mentén találhatók és kb. 80\% fölötti arányban a magyar nyelvezetủ sírfeliratokat tartalmaznak.

A legtöbb szovjet sírral a beregszászi református temető A, B és C parcellájában találkozunk, valamint a sírkerten belül a főbejárattól egyenes úton a temetőbe vezető sétaút mellett található $X$ parcellában. Az akkori temető széleire temették őket, hogy könnyen megtudják közelíteni a sírt és ne kelljen a temető közepében keresniük. Az A és C parcella sírjai tele vannak kommunista szimbólumokkal és orosz nyelvűekkel, ezáltal megfigyelhetünk egyfajta réteges temetkezést, mivel a friss sírokat általában a parcella széleire temették. Tehát ma a parcella határainál leginkább ukrán és magyar sírokkal találkozunk. Levonhatjuk azt a következtetést, hogy a temető magjában és keleti, északkeleti részén található sírok többségben magyarok, az idő során a szláv nemzetiségủek a peremére temetkeztek, így egyre inkább bővült a temető területe nyugati és déli irányban.

A történelmi sorsfordulók mentén nem húzhatunk éles határt a temetőben, ám megfigyelhetjük, hogy az 1840-60-as évektől, az Osztrák Magyar Monarchia idejében temetkeztek leginkább a temető G, H, J, K, L, D, X és Y vagyis középső parcelláiba. A későbbiek ezek köré szerveződtek. Azok a személyek, akik a szovjet érában éltek és a Kommunista Párt szolgálatának szentelték magukat, leginkább az A, B, C, S és X parcellában vannak. A legújabb sírok, vagyis a 20. század második felétől számítva napjainkig a parcellák határaiban, de ha konkrét parcellát kell megneveznünk, akkor leginkább az $\mathrm{L}$ déli részén, az $\mathrm{M}, \mathrm{P}, \mathrm{W}$ és $\mathrm{R}$ parcellákban találjuk.

Elkerülhetetlen a munkánkban a német és a cseh feliratú síremlékek megemlítése is, amiből rendkívül keveset találtunk a temetőben. Két cseh gyermek sírt kell bemutatnunk, amelyet a B és E parcellákban találtunk. Itt párhuzamot vonhatunk a fent említett korszakokra és területekre bontható temetkezéseket, hiszen a szovjet sírok között leltünk rájuk. A B parcellában egy cseh gyermek sírra bukkantunk: 


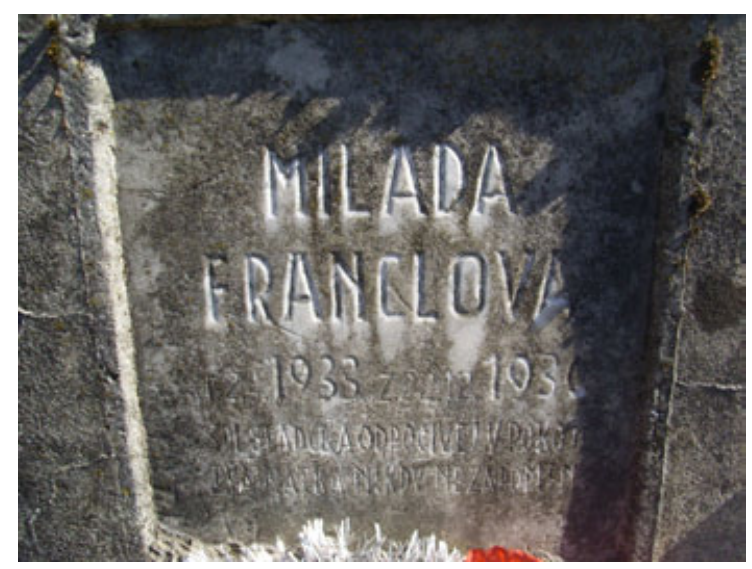

MiladA FranClOVA

1933. 2. 1.- 1936. 12. 22.

DI STADU A ODPOCIVLI V POKOLIVA NA KANIKOV

NEZAPOMEN

Valamint egy másik gyermeksírra, mely cseh-magyar nyelvezetü volt az E parcellában. Magyar felirata a következő:

KONFRST JÁROSLAV

élt 5 évet

mh. 1929. V. 31.

Béke lengjen kihült porai felett.

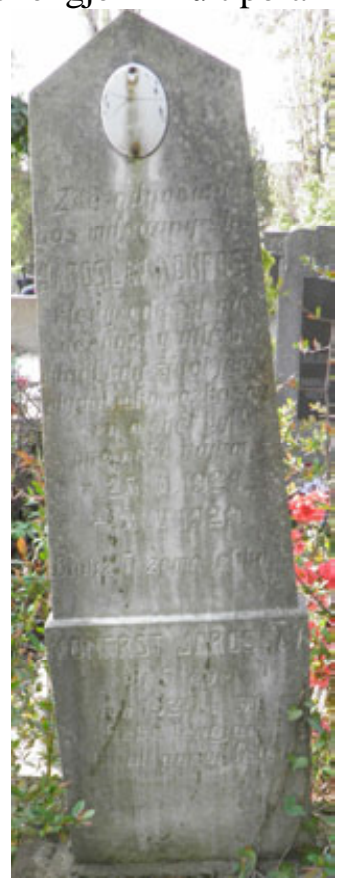

A cseh sírok csekély száma azzal magyarázható, hogy a legtöbb ideirányított cseh és szlovák tisztségviselő az itt töltött alig 20 éves szolgálat során nem ide 
temetkezett, hanem a magyar visszacsatolást követően elhagyták a területet és csak a közben itt született és meghalt gyerekek egy része lelt itt nyugvóhelyre.

A német sírokat illetően meg kell említenem a német hadisírokat, amelyeket a temető L parcellájában találhatunk, sírfelirataik olvashatatlanok.

A beregszászi temető tartalmi összetételének megállapításánál súlyos hiányosságba ütköztünk, hiszen az egykor ruszin nemzetiségü elhunytakat sem nyelvileg sem anyakönyvi kivonatokban nem különböztetik meg. Dr. Árpa István munkájában olvashatjuk, hogy a „megszünt ruszinoknak nevezett állampolgárok (az állami szervek nem csekély közremüködésével) ukrán nemzetiségüeknek neveztettek. Ez az áldatlan állapot mindmáig tart.” Ez azt a következményt vonja magával, hogy a városba bekerült, beköltözött ruszinok nemzeti identitása súlyosan sérült. A városban nincs lehetőségük olyan nagy intenzitással gyakorolni hagyományaikat, valamint az állami nyilvántartásban és a személyigazolványokban is ukrán nemzetiségüeknek vannak bejegyezve. Előbbi levezetésemet azért tartottam fontosnak, hiszen a temetőben található sírfeliratokból sajnos nem derül ki az elhunyt pontos nemzetisége, hiszen nyelvhasználatára vagy csak az ukrán vagy pedig az orosz a jellemző. ${ }^{9}$

Mivel a 2001-es népszámlálási adatok szerint Beregszász lakosságának 48\% - a magyar nemzetiségü, ez a temetőben regisztrált szám arra utal, hogy a magyarok fogyása az utóbbi 1-2 emberöltő időszakában zajlott le és a múltban ettől a részaránytól jóval számottevőbb volt. A következő táblázat azt mutatja be, hogy szinte egy évszázad alatt Beregszász lakosságának magyar nemzetiségü lakossága hány százalékban volt a város összlakosságához képest.

A temető sírfeliratainak nyelvezete és névanyaga alapján elmondható, hogy ugyanez az arány mutatkozik, hisz itt is valamivel több, mint 50\%-os a temetö magyar jellege.

\begin{tabular}{|c|c|c|c|}
\hline Év & Lakos & Magyar & \% \\
\hline $\mathbf{1 9 1 0}$ & 12933 & 12432 & 96,1 \\
\hline $\mathbf{1 9 3 0}$ & 19007 & 9190 & 48,4 \\
\hline $\mathbf{1 9 8 9}$ & 29763 & 15125 & 50,8 \\
\hline $\mathbf{2 0 0 1}$ & 26554 & 12785 & 48,1 \\
\hline
\end{tabular}

1. táblázat:

Saját szerkesztés Molnár József-Molnár D. István, 2005. alapján. ${ }^{10}$

Tehát levonhatjuk a következtetést, hogy a beregszászi református temető nemzetiségileg és vallásilag vegyes. Ezt azzal is magyarázhatjuk, hogy a 20. század elején az ortodox vallásúaknak nem volt sem saját temetőjük és papjuk, aki eltemette volna őket (majd később jelennek meg nagyobb számban a városban). A

\footnotetext{
${ }^{9}$ ÁRPA ISTVÁN: i. m., 27.

${ }^{10}$ MOLnÁR JÓZSEF-MOLNÁR D. ISTVÁN: Kárpátalja népessége és magyarsága a népszámlálási és népmozgalmi adatok tükrében. Beregszász, 2005. 30.
} 
Beregszászi Református Egyház 1942-1962 évek közötti halotti anyakönyvében ${ }^{11}$ olvashattuk nem egyszer azt az esetet, hogy vallási és nemzetiségi (ami akkor hasonló szerepet töltött be) vegyes házasságokból elhunytakat csak a református egyház temetett el és értelem szerüen a református temetőbe. Ezzel is magyarázható az, hogy Beregszász temetői közül itt van a legtöbb cirill betűs sírfelirat, ami ezzel együtt az ortodox vallásúakat is jelenti. Tehát a beregszászi református temető névanyagának és leginkább nyelvezetének a vizsgálatát gazdagította az, hogy vallási szempontból Beregszász történelme folytán minden megjelent vallást megtalálunk. Területi elhelyezkedésük pedig hagymaszerüen rétegzett, vagyis a temető területének közepén található erős magot képező magyar sírok meg fognak maradni addig, ameddig magyarok is fogják lakni Beregszász városát, s több tíz év múlva már élesebb határt lehet majd húzni a nemzetiségi összetétele alapján a temetőnek, hiszen észak-keleti irányba haladva leginkább magyar sírok maradnak, dél-nyugati irányban pedig szláv nemzetiségüek.

\section{Magyar és cirill betüs feliratok összehasonlító elemzése}

Emberek milliói élnek olyan környezetben, ahol nem csak egy, hanem több nyelv használatos. Így például a mai Kárpátalja területén számos nemzetiség képviselöi élnek egymás mellett (sok településen együtt is), és ezek a közösségek különböző nyelveket használnak. ${ }^{12}$ Nincs ez másként Beregszász városában sem, melynek lakossága nemzetiségi szempontból vegyes. Békésen megférnek egymás mellett az orosz-, ukrán-, ruszin-, magyar-, korábban cseh- és német anyanyelvủek egyaránt. Nyelvhasználatuk folyamatos kölcsönhatásban van, gyakoriak a városban a nemzetiségi vegyes házasságok. Ennek következménye az identitás választás és megtartás fontos kérdése. Balassa Iván szerint: „A temetö - az élő falu”, s ezt a kijelentést tökéletesen rávetíthetjük a beregszászi református temetőre is. A sírkert tartalmának nemzetiségi összetétele, mint élő lakosságának tükrözése - vegyes. A lakosság írásbeli nyelvhasználatát a temető sírfeliratai hủen tükrözik.

A mindennapi életben a beregszászi lakosság, köteles az állam nyelvét használni a hivatalos intézményekben. Ez nagy befolyással van az emberek nyelvhasználatára, következménye, hogy akkor is használják, amikor már nem szükséges. A temető emellett sokkal zártabb annál, hogy a politikai hatalom meghatározza azt, hogy mi álljon sírunkon. Ám a sírfeliratok leginkább két pólusú függéssel vannak: az elhunyt, de még inkább a hozzátartozó, aki készítteti a síremléket. A beregszászi református temetőben számos példa van kétnyelvü sírokra, a szláv és magyar kölcsönhatásokra. Az alábbiakban képekkel szeretnénk ezeket a kijelentéseket alátámasztani.

A beregszászi református temető Y parcellájában találjuk a képen látható dupla síremléket. Nyelvi tulajdonságait tekintve kétnyelvü: a baloldali orosz, míg a jobboldali magyar nyelvü. A sír arra ad következtetést, hogy Лесков Николай Федорович Leszkov Konsztantyin édesapja volt, édesanyja viszont magyar

\footnotetext{
${ }^{11}$ Beregszászi Református Egyház Halotti anyakönyve 1942-1962.

${ }^{12}$ CSERNICSKÓ ISTVÁN: Nyelvek, emberek, helyzetek. Ungvár, 2010. 7.
} 
anyanyelvü. A család kétnyelvü volt, az apa orosz és ezen a nyelven is kommunikált vele a család, hiszen felirata orosz, s az aláírás a sírvers alatt magyarra fordítva: Szerető feleséged és fiad áll. Viszont az anya magyar volt, mivel fiúk sírjának felirata már magyar nyelvü és feliratán ez az aláírás áll: Szerető édesanyád. A gyermek névválasztásakor a férj akarata érvényesült, ám anyanyelve mégis magyar lett. A síremlék jól példázza a nemzetiségi vegyes házasságokat.

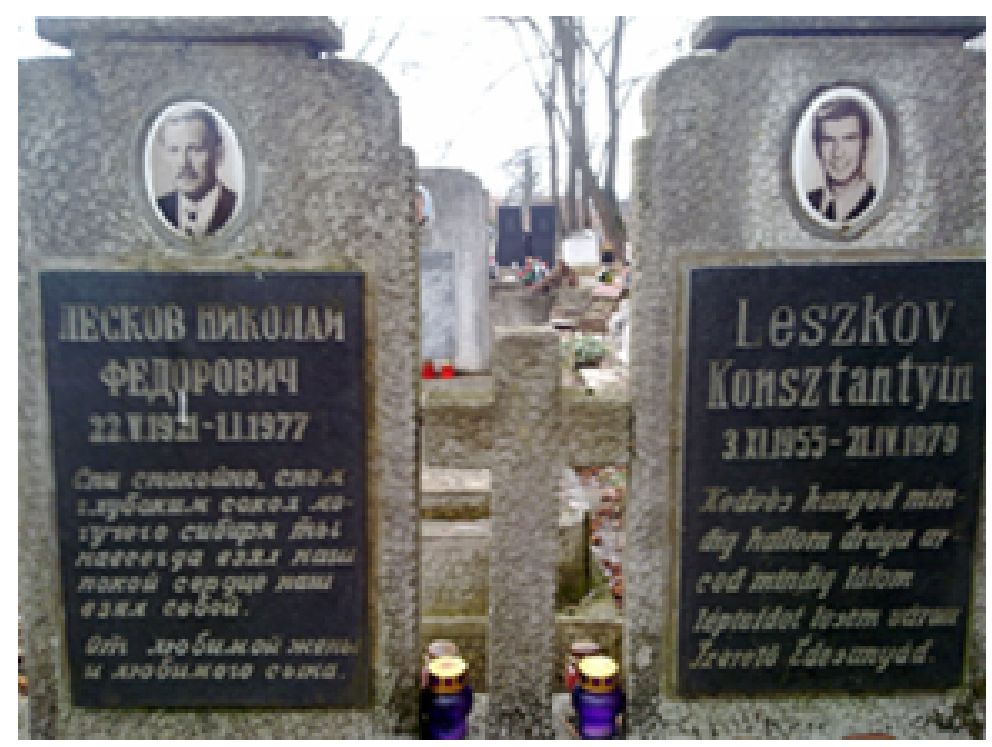

Előfordul az az eset, amikor egyazon síron két nyelven vannak feltűntetve tulajdonosának az adatai. Ezt valószínüleg az magyarázza, hogy a felirat olvasója akár magyar, akár orosz anyanyelvü, megértse, hogy kit rejt a sír. Meg kell említenünk emellett, hogy a példára felhozott síremlék a Szovjetunió idejéből származik. 


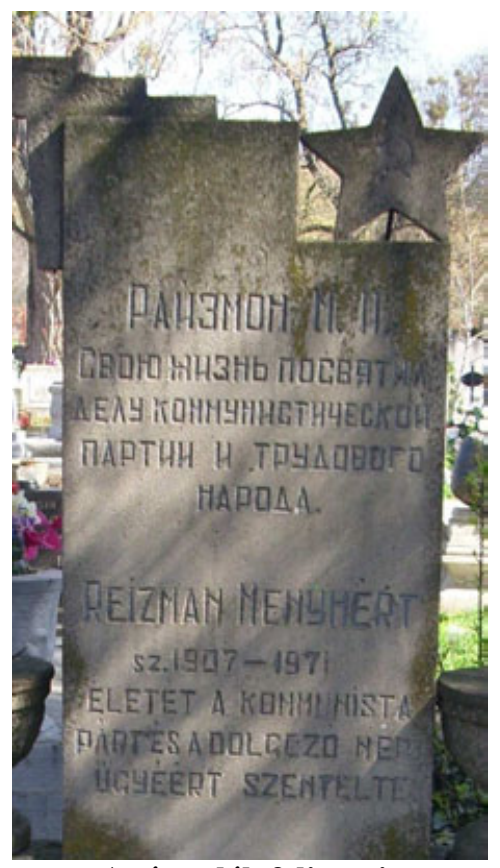

A síremlék feliratai:

РАЙзмон М. И.

СВОЮ ЖИЗНЬ ПОСВЯТИЙ ДЕЛУ КОММУНИСТИЧЕСКОЙ ПАРТИИ И ТРУДОВОГО НАРОДА. REIZMAN MENYHÉRT SZ. 1907-1971

ÉLETÉT A KOMMUNISTA PÁRT ÉS DOLGOZÓ NÉP ÜGYÉÉRT SZENTELTE

Reizman Menyhért nevéből következtetve magyar nemzetiségű volt, a társadalomban és a pártban betöltött szerepe viszont elengedhetetlennek bizonyult az orosz nyelv mindennapi használata. Ez a példa hüen tükrözi azt, hogy Beregszász lakosságának már a 20. század közepén is mindennapos volt a többnyelvüség. A következő példákban a szláv apanév használatát szeretnénk vizsgálni, hogy hogyan jelenik meg a temető magyar nyelvü sírfeliratain, valamint a fordított verzióját, annak elhagyását.
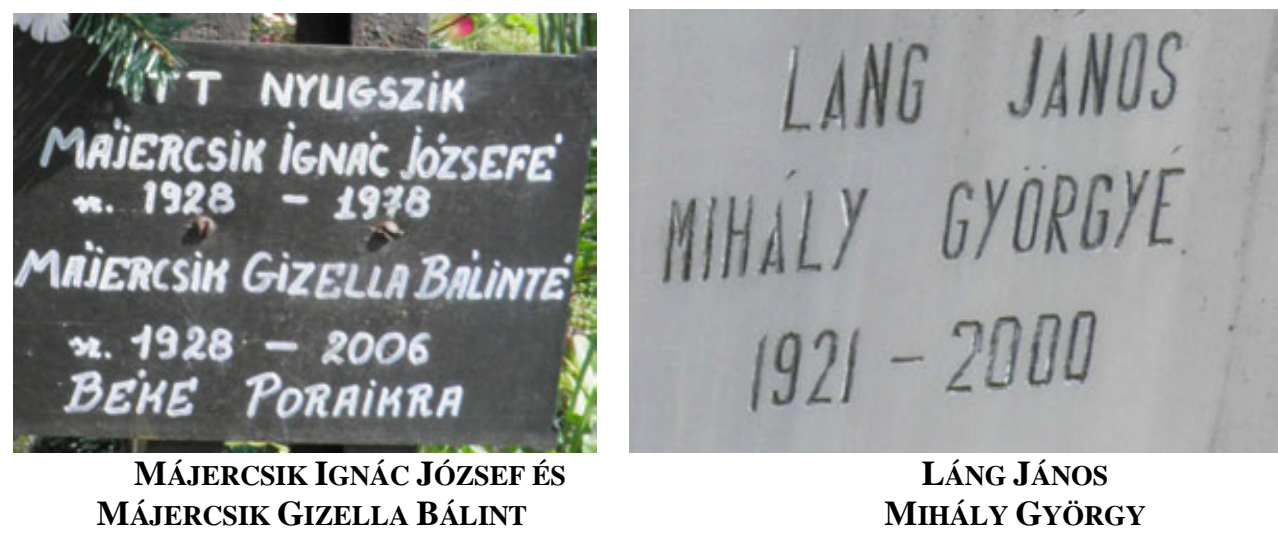


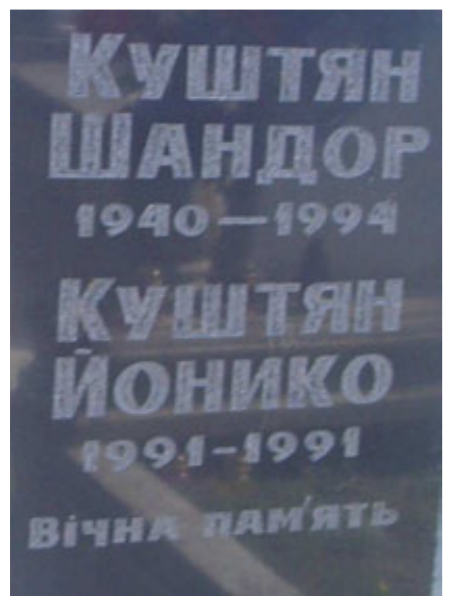

КУШТЯН ШАНДОР

1940-1994

КУШТян Йонико

1991-1991

ВІЧНА ПАМ $\square$ ЯТЬ

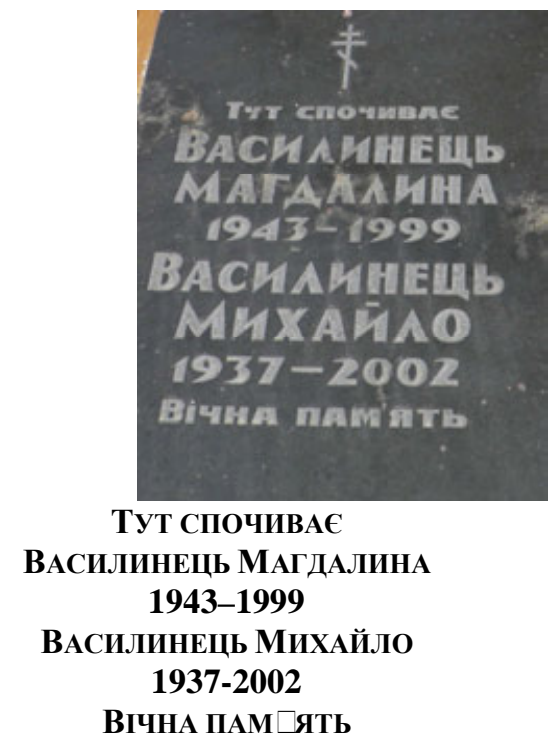

Куштян Йонико és édesapja Куштян Шандор nevének elemzésekor feltételezhetjük, hogy a sírkészíttető hozzátartozó már nem beszélt magyarul, ám a keresztneveket megfigyelve tipikusan magyar nevekről beszélünk: Sándor és Janika. Hasonló példa erre a következő síremlék: ЛЕНДьЕЛ ЮЛИАННА МИХАЙЛОВНА

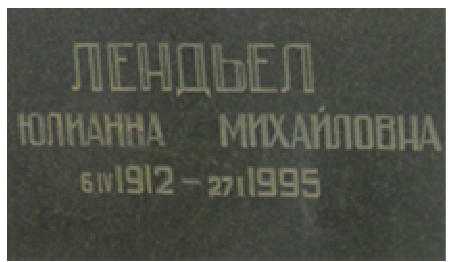

Fordított esetet is találunk a beregszászi református temetőben, amikor egy orosz név van magyarul felírva, szintén vegyes házasságról beszélünk: NAGY DÁRJá IVÁNAVNÁ

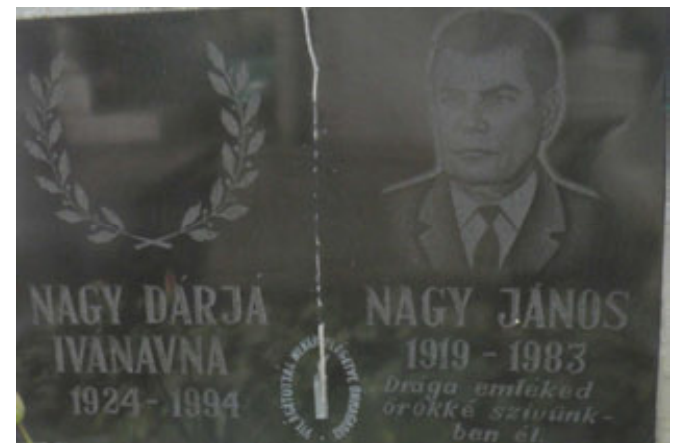

Beregszász lakossága már korábban is többnyelvü volt. Nemcsak az utcán járva találkozunk kétnyelvü feliratokkal, hanem a temető sírfelirataiban is él a másik 
nemzet nyelvének, hagyományainak tiszteletben tartása (lásd az apanév használat) és alkalmazása.

\section{A fejfák díszítése és szimbólumvilága}

A fejfa a halott képmásából (bálványból) személyi adatokat tartalmazó „emléktábla” lett. Antropomorf elnevezések is a fejfa-formák emberalak-eredetére utalnak: láb, derék, mejj, váll, nyak, konty, törzs, homlok, szemöldök, kaláris (gyöngysor). A fejfán régen nem volt írás, a jelrendszeréből lehetett következtetni a halott nemére, katonai rangjára, vitézi, hősi tetteire, családi állapotára, korára, társadalmi és vagyoni helyzetére, elhalálozás idejére. ${ }^{13}$

A fejfákról már távolról megállapítható volt, ki nyugszik alatta, anélkül, hogy a feliratot elolvastuk volna. Ezen jelképek, díszítmények megóvása nem csak egy hagyomány továbbélésének lehetőségét adja meg az utókor számára, de tiszteletet is nyújt az ősök, az elődök emlékezetének. ${ }^{14}$ Valamint ezeket a motívumokat a mai napig használják, ismerik azok jelentését. Sokszor ezek a szimbólumok a vallási hovatartozást akarják jelezni. Katolikus síremlékeken jellemző Szűz Mária vagy Jézus, angyalok ábrázolása. De gyakran többről van szó, mint közvetlen szimbólumok halmozásáról. Ilyen például, amikor különböző növényi motívumokkal, állati ábrázolással látják el a fejfákat.

A szimbólumok saját kultúránk és valamennyi emberi civilizáció megismeréséhez elvezetnek, hiszen gondolkodásmódunk alapvető sajátossága a (jel)képek használata. A környezet természeti jelenségei, élőlényei és maguk az ember teremtette tárgyak is a képalkotás alapszókincsébe tartoznak. Minden a világról alkotott tudás kifejezőjévé és érzéki szemléltetőjévé válhat. Például a fény, az ég mindenütt a menny, az istenség, a földön túli erő szimbóluma, és a sötétséghez egyetemes érvénnyel kapcsolódik a pusztulás, a halál képzete. ${ }^{15}$

A szimbólumok világát gyakran tekintik titkosnak, misztikusnak. Ebben az értelmezésben - a hieroglifákhoz hasonlóan - meg kell fejteni és újra meg kell tanulni jelentésüket. Kétségtelen, hogy bizonyos jelek - elsősorban a nem képszerü (non-ikonikus) szimbólumok, például a geometrikus jelek - kizárólag az azokat megalkotó kultúra ismeretében értelmezhetők, vagy - forrásértékü adatok híján örökre némák maradnak. De a jelképek döntő hányada, a képszerü (ikonikus) jelek olyan természetességgel hordozzák jelentéseiket, hogy értelmezésük kézenfekvő. Nem igényel magyarázatot az, hogy az oroszlán elsődleges szimbolikus jelentésében miért a hatalom és az erő, a bárány pedig miért a gyengeség és a szelídség megtestesítője. ${ }^{16}$

Kunt Ernő szerint a síremlékek szimbólumai csupán csak díszítő motívumként szerepelnek, ám nem zárja ki az üzenet- és személyes információ tartalmát sem.

\footnotetext{
${ }^{13}$ Kós KÁROLY: Népélet és néphagyomány. Bukarest, 1972. 227-237.

${ }^{14}$ BALASSA IVÁN: A magyar gyász-színek kérdéséhez. Ethnographia, LVI (1945) 69-70.

${ }^{15}$ PÁl JÓZSEF-ÚJVÁRI EDIT: Szimbólumtár. Bp., 2001. /http//:balassikiado. hu/BB/netre/Net_ szimbolum/szimbolumszotar.htm (letöltés dátuma:2014. 02. 10.)

${ }^{16}$ PÁL JÓZSEF - ÚJVÁRI EDIT:, 2001.
} 
Munkájában leírja, hogy a leggyakoribb szimbólumok, azok a szív, csillag, virág, bimbó, fa (szomorúfüz), esetleg stilizált madár ábrázolások. A kód legkisebb elemének a síkbeli díszítmények egy motívumát, alapelemét tekintjük. (Egy fejfán általában egy motívum szokott szerepelni.) ${ }^{17}$

A szimbólumok azért voltak nagyon fontosak a keresztény egyházak számára, mert a segítségükkel az írástudatlan embereket is tanítani tudták. ${ }^{18}$

A beregszászi református temetőben számos szimbólummal találkozunk a síremlékeken. Mind különleges üzenetet hordoz. Hol az elhunytról mesélnek, mint például a vallási hovatartozását jelölő, szakmájára utaló, korai halálát jelző jelképek; hol pedig a politikai hatalom és eszme befolyása mutatkozik meg a síremlék szimbólumán. A sírkertben talált szimbólumokat a következő kategóriákba csoportosítottuk:

Vallási hovatartozást jelölő szimbólumok - az elhunyt hozzátartozója fontosnak tartja feltűntetni, hogy melyik felekezethez tartozott szerette, valamint ezáltal megkülönböztetésre kerül a tőle eltérő vallásúaktól. A beregszászi református temető átfésülése alkalmával rengeteg ilyen szimbólummal találkozunk, amelyek többnyire minden temetőben előfordulnak, így tipikus keresztény jelképekről beszélünk. Az itt fellelt szimbólumok közül a leggyakoribbak az alábbiak, melyek jelentését Pál József - Újvári Edit szimbólumtára valamint Hoppál Mihály jelképtára alapján definiáltuk:

A katolikus vallásúak leggyakoribb jelölése a kereszt - amely az egyetemes jelképek közé tartozik. Rajta halad keresztül a világ tengelye. Minden körülötte forog. Itt található a világegyetem középpontja, ő maga a világfa, Jákob lajtorjája, az eget és a Földet összekötő kapocs. Egyszerre jelképezi a szenvedést és a megbocsátást. ${ }^{19}$

A kereszt legrégebbi és legelterjedtebb szimbólumok közé tartozik; számos mitologikus és vallási rendszerben megtalálható. Jézus Krisztus második eljövetelekor az „Emberfia” jele (Mt 24,30). Nagy Konstantin császár számára Krisztus keresztje a győzelem jele: „In hoc signo vinces” (E jelben győzni fogsz). A teológiai erények közül a Hit allegorikus alakjának attribútuma. Az ókeresztények a kereszt helyett gyakran titkos ismertetőjelet alkalmaztak (hal, horgony). A középkorban azt tartották, hogy Krisztus keresztjét a tudás fájából készítették. Egy másik hagyomány szerint az élet fájából készítették, és ezért képes feltámasztani a halottakat (Jel 2,7; 22,2). Hasonló kontextusban jelenik meg egy középkori német szövegben is a kereszt: olyan fa, amelynek gyökerei a Pokolba nyúlnak, csúcsa Isten trónusánál van, és ágai között tartja a világot. Szimbolizálhatja a halált vagy a szenvedést, és az áldozat elfogadását. ${ }^{20}$

A felekezeti életben is változások mentek végbe Kárpátalján. Találunk olyan települést, amelyek felekezetileg „tisztának” mondhatóak, tehát katolikusok, máshol reformátusok vannak többségben. 1946-tól az eddig csak görög katolikusoknak

\footnotetext{
${ }^{17}$ KUnT ERNŐ: Magyar népi temetők szemiotikai elemzése. In: A Herman Ottó Múzeum Évkönyve XIII-XIV. 475-507.

${ }^{18}$ BERYL DHANJAL: Jelek és jelképek. Múlt és jelen. 2011. 98.

${ }^{19}$ BERYL DHANJAN: i. m., 102.

${ }^{20}$ PÁL-ÚJVÁRI: i. m., 2001.
} 
regisztráltak helyébe egy módosítást eszközöltek, ami megkülönbözteti már az ortodox és pravoszláv felekezethez tartozóakat is. ${ }^{21} \mathrm{~A}$ felekezeti megkülönböztetést könnyítették a kereszt szimbólumok, amelyeket egyértelmüen jelölik, hogy a síremlék tulajdonosa ortodox, görög- vagy római katolikus felekezethez tartozott.

A beregszászi református temetőben talált legtöbb kereszt a latin kereszttel egyezett meg, amelynek egymással merőleges szárai nem egyenlő hosszúak: a függőleges szár jóval hosszabb, mint az azt metsző vízszintes. A keresztek világa és megkülönböztetése roppant izgalmas területe volt kutatásunknak, mivel nemcsak latin keresztekkel találkoztunk a sírkert körbejárásakor, hanem hármas keresztekkel is. Két változatát ismerjük: az egyikben az alsó kereszt szál azonos hosszúságú a felsővel, amelyet ma a görög-katolikus egyház használ; a másik változatban már az alsó kereszt szál ferdén van ábrázolva - ezt az ortodox, más néven pravoszláv vallásúak használnak. A ferde szálat azzal magyarázzák, hogy az szolgált Jézus felszögezett lábának támasztékául.
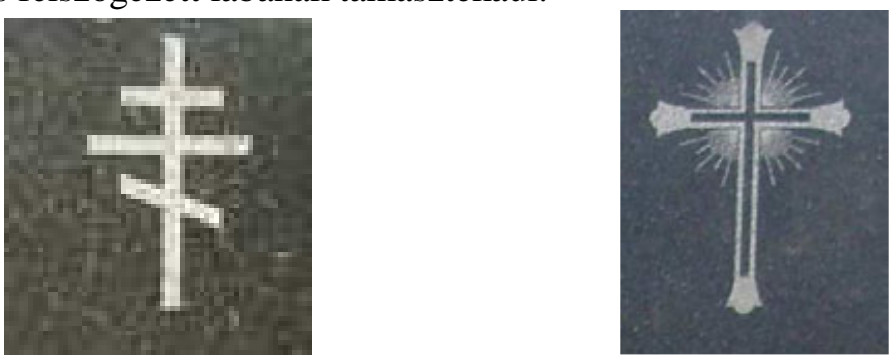

A katolikus jelképekhez tartoznak még a következő szimbólumok, amelyek megtalálhatóak a beregszászi református temetőben: Szüzanya, feszület. A Szüzanya, vagy más megnevezésben Szüz Mária szerepe a síremlékeken több jelentésủ. A katolikus egyházban a hívők számára a szentek közbenjáró feladatkörrel bírnak Istennél, a református egyháztól eltérően, ahol csak Jézus Krisztus tölti be ezt a szerepet. Így Szűz Mária képét csakis katolikus vallású sírokon találjuk meg. A temetői szimbólumvilágban jelenléte többértelmü: védelmezi a lelkeket és biztosítja helyüket a Paradicsomban.

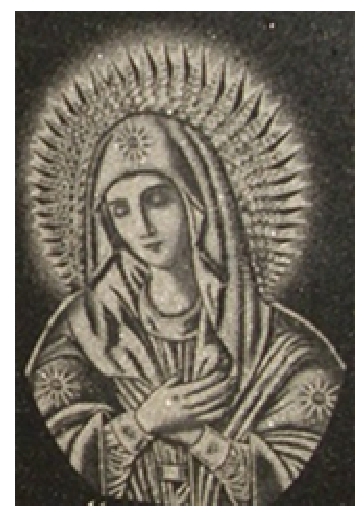

${ }^{21}$ ÁRPA: i. m., 23-26. 
Számos síremléken találkozunk feszülettel, amely a keresztre feszített Jézus Krisztus jelképe. ${ }^{22}$ Ilyeneket az V. századtól kezdve ismerünk, mert korábban a keresztre feszítés megalázó voltának eleven emléke miatt (csak a legelvetemültebb bünözőket és a rabszolgákat sújtották ezzel a kivégzési móddal) egyszerü kereszttel vagy rajta látható hallal ill. báránnyal szimbolizálták Krisztus kereszthalálát. $^{23}$

A református szimbólumokhoz tartozik a kehely és a szomorúfüz. A csüngő ágú füz a panaszok fája volt, innen kapta nevét: szomorúfüz. ${ }^{24}$ Molnár Mihály úgy véli, hogy a szomorúfüz általános szimbólum, amely mind a keresztény, mind a zsidó sírjeleken megtalálható. ${ }^{25}$ Balassa Iván szerint viszont a szomorúfüz kimondottan a reformátusság halálábrázoló szimbóluma, amely legelőször Debrecen környékén tünt fel, és innen terjedt a magyar nyelvterület szélei felé. ${ }^{26} \mathrm{~A}$ fejfa részének fö, egyben központi motívuma a füzfa vagy egyszerübb formájában az inda motívum.

\section{„Szomorú füz hervadt lombja,}

Ráhajlik a sírhalomra."

Az inda motívum kiinduló pontja lehet az egy vésetű föld jelzésből vagy az edény különböző formátumaiból. A füzfa ábrázolása a stilizált egy vésetű törzzsel rendelkezőtől kezdve, a gazdagabb kialakítású 3-7-9 elágazású füzfáig terjed. A füzfa törzse egyvésetü, kettős hullámvonalú vagy törzsábrázolású is lehet. ${ }^{27}$
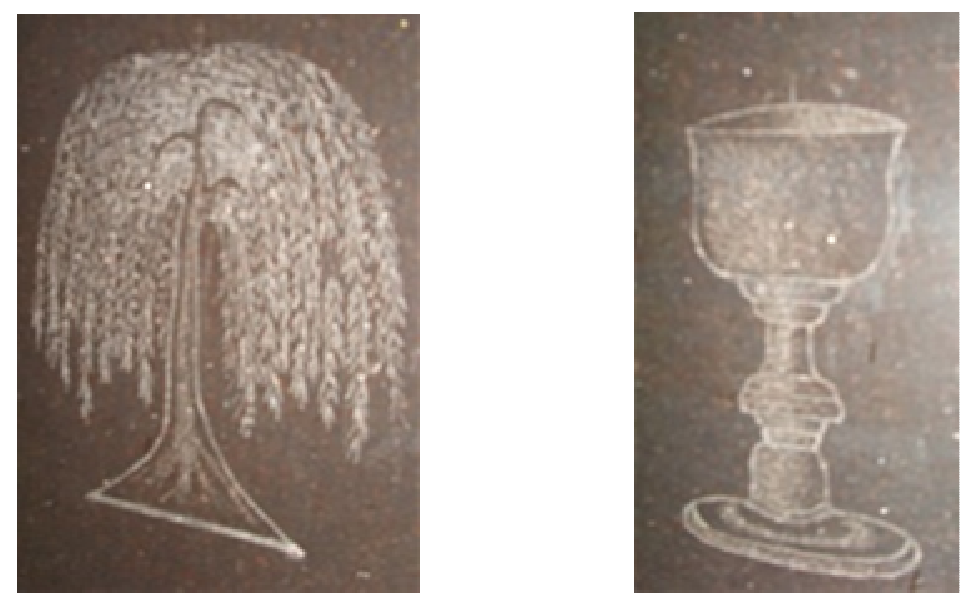

A kehely - tipikus protestáns jelkép. Ezzel a szimbólummal jelzik, többnyire a református vallási hovatartozású elhunyt sírján azt, hogy milyen vallást gyakorolt.

\footnotetext{
${ }^{22}$ PÁ L-ÚJVÁRI: i. m., 2001.

${ }^{23}$ HopPÁL M. - JANKOVICS - N. A.- SZEMADÁM: i. m., 68.

${ }^{24}$ Szimbólumok lexikona. Szerk: Michel Guillemot-BethSABÉE Blumel. Paris, 2009. 179.

${ }^{25}$ MOLNÁR MiHÁLY: Sírfeliratok a magyarországi Gömörben. Gömör néprajza LIV. Debrecen, 2000. 6.

${ }^{26}$ BALASSA: i. m., 76.

${ }^{27}$ DomanovszKy GYÖRGY: Beregmegyei fejfák. A Néprajzi Múzeum Értesítője. A Magyar Történeti Múzeum Néprajzi Osztályának folyóirata, XXVIII. (1937) 1-4. sz. 97.
} 
Díszes, talpas ivóedény. A serleg, a pohár, a csésze és a kehely hasonló funkciójú és szimbolikájú edények. A zsidó és keresztény hagyományban szintén gazdag jelentésrendszer kapcsolódott hozzá. Az Ószövetségben Ábrahám és Melkizedek találkozásakor, a Melkizedek által használt boroskehely a tipológiai szimbolizmus szerint az eucharisztia kelyhének előképe (Ter 14,18). Jelentheti Isten büntetését, haragját, a pusztítást (Iz 51,17-22; Zsolt 75,9). Ezzel szemben a teli, túlcsorduló pohár Isten adománya, jótéteménye, a szabadulás (Zsolt 23,5). A keresztény liturgiában a kehely a mise során az átváltozó bor befogadására szolgáló talpas ivóedény. Ez a „kehely csodája”, a mysterium calicis, amely az Utolsó vacsorára és Krisztus feláldozására utal (Mt 26,27-28). Ezért a kehely a keresztény hüség jelképe, a teológiai erények közül a Hit attribútuma. Pál apostol az 1Kor 10,16 versében utal a Krisztussal való közösségre, amely a kehely által valósul meg. A keserü pohár a mártírium és egyben az üdv kelyhe is (Mt 26,39-42). ${ }^{28}$

Keresztény szimbólumként tartjuk számon az urnát is, amely ritka a beregszászi református temetőben, ám akad példa előfordulására. A temetési urnák, melyek a halott hamvait tartalmazzák, bizonyos értelemben az anyaméhet, az anyaföldbe való visszatérést jelképezik, de a ház szimbolikájához is kapcsolódhat, hiszen az urnák a halott földi maradványainak végső lakhelyéül szolgálnak. A keresztény szimbolikában a temetkezési urnák Krisztus sziklasírját idézik. ${ }^{29}$ A bölcső-ágykoporsó hármasság által jelzett életfolyamat utolsó stádiumának, a halálnak a megjelenítője. Az urnából kitörő tüz a feltámadás, a halál utáni élet jelképe. Egyiptomi ábrázolásokon a mérlegre állított urna a halott lelke (mérleg). A római ember és ház alakú halotti urnák a „lélek” és a „test” jelentést is hordozták. ${ }^{30}$

$\mathrm{Az}$ alábbi kategória a politikai hatalomváltást jelképező szimbólumokat tartalmazza. Ezek a hatalomváltások nagy befolyással voltak az emberek életére, mindennapjaira. Leginkább a kommunista diktatúrát kell kiemelnünk, amikor is a kor eszméje befolyásolta a lakosság gondolkodását és a dolgokhoz való hozzáállását. Arról az időről beszélünk, amikor Beregszász internacionalista lakossággal rendelkezett, nemzetiségtől függetlenül dicsőség volt szolgálni a Szovjet Szocialista Pártot, és hatalmas hőstett meghalni annak zászlaja alatt. Ezért az akkor élt, majd meghalt emberek fontosnak tartották azt, hogy sírjuk megkülönböztetve legyen azáltal, hogy jelzik szolgálatukat. Ennek következtében számos kommunista szimbólummal találkozunk a sírfeliratok mellett a síremlékeken. A kommunista csillag mellett megtaláljuk a sarló-kalapácsot is, valamint a Szovjetunió kiolthatatlan lángját éltető szovjet csillag, a búzakoszorú, valamint egy földgömb, amelyet a sarló-kalapács szimbólumon keresztül látunk.

\footnotetext{
${ }^{28}$ PÁL-ÚJVÁRI: i. m.

${ }^{29}$ Uo.

${ }^{30}$ Uo.
} 

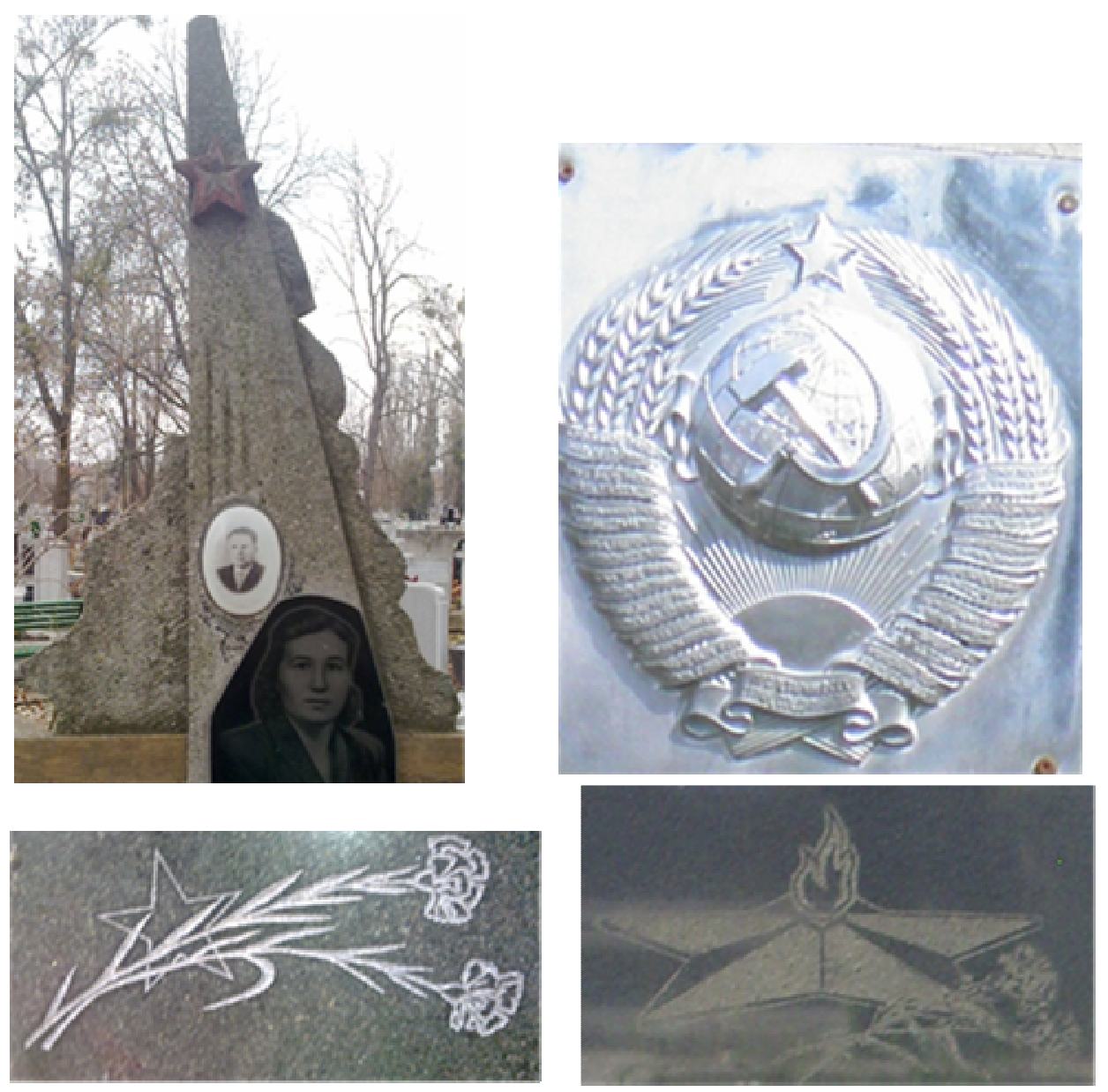

A sírkertben található egyik legérdekesebb szimbólumkombináció épp kommunista ideológiai hatású. Egyedisége sokoldalúságából eredeztethető, hiszen több oldalról megvilágítható, s az értelmezések különböző variációi tárulnak elénk. A síremléken található kommunista csillag, közepében a sarló-kalapáccsal egészen átlagosnak tekinthető. Ám alatta helyezkedik el egy szimbólum, amely semelyik értelmezésben nem illik a szovjet ideológiához. Az első értelmezésben egy szocialista-realista stílusú szomorú füzfát látunk, amely bár nem hagyományos módon van ábrázolva, mégis első ránézésre a fára asszociálunk. De ha jobban megvizsgáljuk, akkor egy hétágú fordított gyertyatartót (menórát) is észrevehetünk. Míg a szomorúfüz egy egyetemes protestáns jelkép, addig a menóra a zsidó vallás pusztulásának és újjászületésének jelképe. A menóra jelképisége a Közel-Kelet legrégibb civilizációiban gyökerezik, az asszírok és a babiloniak hétágú szent fájáig vezethető vissza, amely az örök élet fáját jelentette. A Kr. u. III. századtól kezdve a menóra feltünik a zsinagógák és a sírok díszítésében, mint az üdvözülés reményének 
szimbóluma. ${ }^{31}$ Tehát, hogy ha ezt a két értelmezést összevetjük, akkor mégis egy faábrázolásra enged következtetni a szimbólum. De hogyan függ össze a kommunista csillaggal? És az örök élet fája az elhunytra vagy a szovjet hatalom örökkévalóságára utal? Szubjektív véleményem nem mérvadó, ám a kérdéseket kötelességem feltenni.

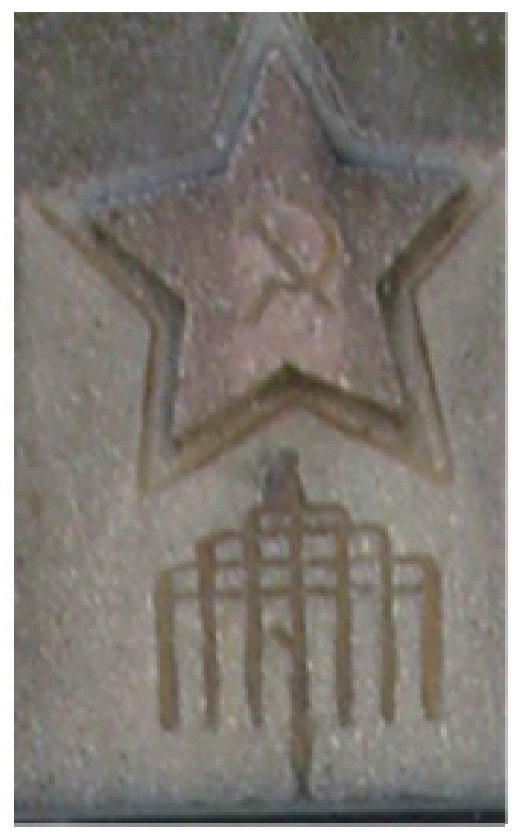

Fentebb már elemeztük a kereszteket és azok jelenlétét a beregszászi református temetőben, azonban vannak olyan keresztek a sírkertben, melyeknek semmilyen köze nincs a kereszténységhez, hiszen ezek vaskeresztek (betonból készültek). Vaskereszt: a görög kereszt geometriailag másfajta ábrázolása, aminek szárai bentről kifelé haladva szélesednek. Előfordul olyan változata is, ami négy darab egy pontba mutató háromszögből áll. Eredetileg a teuton lovagok keresztje volt, később katonai kitüntetés és azonosító jelzés lett belőle. A beregszászi református temetőben három ilyen keresztet találunk az $\mathbf{L}$ parcellában, amelyek német katonai sírok lehetnek.

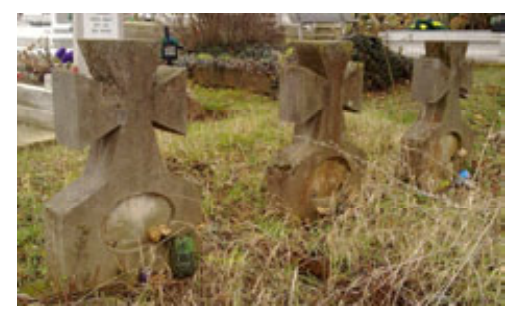

${ }^{31}$ Szimbólumok lexikona: i. m., 194-195. 
Gyakran botlunk bele jelképes számokba, ilyen például a két szál (rózsa, liliom, szegfü, stb) virág, melynek páros száma határozottan a gyászra utal.

A temető szimbólumvilágának elemzését egyfajta kapcsolatteremtésnek is tekinthetjük az elhunyttal. Hiszen ők a múlt tanúi és síremlékeik vizsgálata alatt egy bizonyos kommunikáció történik, amely alatt elmesélik életük történetét. A kutató dolga csak egy, helyesen értelmezni a kapott információkat. Kunt Ernő munkájában egyfajta kommunikációs modellt határozott meg, amely azt bizonyítja, hogy „azért nevezhetjük a temetöt kódrendszernek, mert megtalálható benne a tárgyi kód (sirjelek, építmények, utak, kerítés stb.), a proxemikus kód (sírok elrendezése, sírjelek egymáshoz való viszonya, közel-távol, bal-jobb stb.), cselekvési kódok (sírásatás, temetési szertartás, a sír gondozása stb.), és az írás kódja (feliratok a sírjeleken)."

Nemcsak egy szimbólum lehet árulkodó jel a síremlék tulajdonosáról, hanem maga a sírfelirat is mesél nekünk rengeteg mindent: az elhunyt nemét, akár származását, foglalkozását. Gyakran ezeknek a sírfeliratoknak rengeteg hasonlóságuk van, a névanyag mellett olvashatunk búcsúszövegeket, bibliai idézeteket, versikéket. A sírfeliratokban kicsi a változatosság és jobbára hasonló formulákat találunk, mégis szükségesnek tartom néhányat bemutatni, mint a népköltészet érdekes hajtását, megjegyezve, hogy itt maga a nép írja azokat és nem a papok vagy a tanítók. ${ }^{32}$

A fejfa- és sírfeliratok az utóbbi másfél évszázad során terjedtek el. Ez idő alatt sajátos müfajt alakítottak ki a népköltészetben - a sírjel költészetét. A Magyar Néprajzi Lexikon szerint „a sirfeliratok síremlékre kerülő vers, amelyben a sírfeliratíró hagyományos motívumok felhasználásával emléket állit az elhunytnak. A sirfeliratok egyéni alkotások, bár a vers váza hagyományos, a sírfelirat-író mindig aktuálissá alakítja. A sírfelirat komoly, tragikus színezetü, kifejezi a család gyászát, verselése gyakran nehézkes, stílusa mesterkélt, ${ }^{, 33}$ ám a feliratos népköltészetről is olvashatunk egy másik kötetben: „rövid, pár soros, általában ritmikus, rímelö, versformában irott szöveg. A feliratok tartalmi szerkesztésmódja azonos szabályokat követ: feltünteti az elhunyt nevét, illetve annak kezdöbetüit, s halálának évszámát. Ezekhez az alapadatokhoz aztán a halott személyére, illetve a rokonság fájdalmának kifejezésére vonatkozó - a sírjelek felirataiban általánosan használt - kiegészító sablonokat füznek. A szöveget minden esetben egy adott sablon nyitja: „Itt nyugszik...”, illetve zárja: „Béke poraira. Nyugodjék békében”. Gyakoriak a röviditések, melyeknek nagybetüs sora egyúttal díszitöelem is, esetlegesen kicifrázott formában. "’34

ABFTIRA $=$ a Boldog Feltámadás Idejének Reménye Alatt

ABFTRA $=$ a Boldog Feltámadás Reménye Alatt

ABFRA $=$ a Boldog Feltámadás Reménye Alatt

$\mathrm{SZ}=$ született

\footnotetext{
${ }^{32}$ PÁL-ÚJVÁRI: i. m., 2001.

${ }^{33}$ Magyar Néprajzi Lexikon 4. Szerk.: Ortutay Gyula. Bp., 1981. 452-459.

${ }^{34}$ DOMANOVSZKY GYÖRGY: Beregmegyei fejfák. In: A Néprajzi Múzeum Értesítője. a Magyar Történeti Múzeum Néprajzi Osztályának folyóirata, XXVIII. évfolyam. 1-4. szám. 1937. Budapest, 98.
} 
$\mathrm{MH}=$ meghalt

$\mathrm{BLPF}=$ béke Lengjen Porai Felett

$\mathrm{BP}=$ béke Poraira

$\mathrm{BH}=$ béke Hamvaira $^{35}$

A kezdőformula (pl: ABFRA), után (ha van) következnek minden esetben az elhunyt adatai: név, életkor, születési-, halálozási dátum, esetleg a foglalkozása. A személyes adatokat követhették az ún. sírversek, melyek mindenkor a család igényeit elégítették ki. A záróformula, mintegy lezárásképpen a belenyugvást, megnyugvást volt hivatott kifejezni.

A sírversek mindenkor a család kívánalmaihoz kötődtek, de mindig az elhunyt adatai és a záró formula előtt kellett, hogy álljanak. ${ }^{36} \mathrm{~A}$ beregszászi református temető ebböl a szempontból eltérö, hiszen a sírfeliratok közül nem találkozunk ABFRA és hasonló formulákkal. A leggyakoribbak a nyitó formulák közül: „Itt nyugszik” és záró formulák között megtaláljuk a „Nyugodjon békében”, „Béke poraira”, „Áldás legyen hamvain” és a „Béke hamvaira” záróformulákat. Mivel a többnyelvüség jellemző a temető tartalmára, így ugyan ezen formulák ukrán (Тут спочиває / Вічна пам'ять) és orosz (,Здесь покоится/ Вечная память) verziója is megtalálható.

A beregszászi református temető sírfeliratait tekintve összességében többnyelvűségről beszélünk. Ami a sírverseket illeti, a szláv síroknál nem jellemző a sírvers használatának a szokása. Leggyakrabban a búcsúzók megnevezése és a síremlék állíttatói vannak feljegyezve a fejfákra, ám a 21. századi sírokon már megjelennek a rímbe szedett sírversek is.

Végezetül meg kell említenem, hogy sírversekkel kapcsolatosan több kiváló munka született, amelyek hatalmas segítségemre voltak a kutatás elvégzésében, mint például Pénovátz Antal $^{37}$ kárpátaljai vonatkozásban pedig Penckóferné Punykó Mária és Borsos Balázs, ${ }^{38}$ valamint Sass Szilvia ${ }^{39}$ müvei.

A kutatás célja tehát egy magyarságismereti vizsgálat volt Beregszász városában a temetők gazdag adattárházát felhasználva. Azokat a kulturális kölcsönhatásokat vizsgálta, amelyeket a politikai hatalomváltások hoztak magukkal az emberek életébe: mind vallási téren, mind a mindennapi életükbe, gondolkodásmódjukba. A különböző kulturális hagyományok egymás mellett való gyakorlása gazdagította és formálta a beregszászi polgárok világra való rálátását.

A temető szimbólumvilágának elemzését egyfajta kapcsolatteremtésnek is tekinthetjük az elhunyttal. Hiszen ők a múlt tanúi és síremlékeik vizsgálata alatt egy bizonyos kommunikáció történik, amely alatt elmesélik életük történetét. A kutató dolga csak egy, helyesen értelmezni a kapott információkat.

\footnotetext{
${ }^{35}$ NAGY DEZSÖ: A magyar fejfák és díszítményeik. FA. 2, 1974.

${ }^{36}$ DANKÓ IMRE: A hajdúböszörrményi temetők költészete. In : A Hajdúsági Múzeum Évkönyve II., 1975. 287.

${ }^{37}$ PÉNOVÁTZ ANTAL: „Megrakom a szekeremet kívís gabonával...”. Zenta, 2010. 154-176.

${ }^{38}$ PENCKÓFERnÉ PUNYKó MÁRIA - BORSOS BALÁZs: Sírversek a Szernye- mocsár környéki magyar falvak temetőiben. In: Néprajzi Látóhatár. I. évfolyam. 1-2. szám. 1992. 154-166.

${ }^{39}$ SASS SZILVIA: Borzsovai sirjelek és sírfeliratok. In: EGYÜTT. IRODALOM- MÜVÉSZETKULTÚRA. 2 szám. 2007. 84-87.
} 